\title{
Tullio phenomenon in superior semicircular canal dehiscence (SSCD)
}

\author{
Richard Pullicino, Reuben Grech
}

Medical Imaging Department, Mater Dei Hospital, Msida, Malta

\section{Correspondence to} Dr Richard Pullicino, richard.pullicino@gmail.com

Accepted 6 December 2015

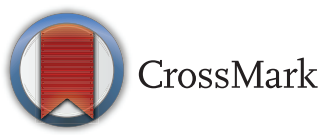

To cite: Pullicino $R$, Grech R. BMJ Case Rep Published online: [please include Day Month Year] doi:10.1136/bcr-2015213674

\section{DESCRIPTION}

A 68-year-old woman presented with worsening sound-induced vertigo (Tullio phenomenon) and left-sided hearing loss. Weber's test lateralised to the affected ear and audiography confirmed mild conductive hearing loss. Neurological assessment was remarkable for torsional/vertical noise and vibration-induced nystagmus. The patient demonstrated low threshold cervical vestibular-evoked myogenic potential responses, and superior semicircular graphy and stapedial reflexes were normal bilaterally.

High-resolution CT of the temporal bones was performed, which demonstrated a bony defect in the apex of the superior semicircular canal (figure 1).

The thin osseous plate covering the semicircular canal may be breached by trauma or erosive processes resulting in corruption of the hydraulic purity of the perilymph. Surgical repair of the defect with fascia or canal resurfacing is effective and provides long-term symptom relief.

While in the majority of cases superior semicircular canal dehiscence (SSCD) is the main pathology in patients with the Tullio phenomenon, other causes include an enlarged vestibular aqueduct and perilymphatic fistulae. ${ }^{1}$ The pathophysiology of this phenomenon is thought to be that the dehiscence of the superior circular canal creates a mobile window in the labyrinth allowing the transmission of low frequency sound waves. This in turn canal dehiscence was suspected. Otoscopy, tympano-

causes movement of the endolymph inside the canal, triggering the vestibular signs and symptoms exhibited in these patients. ${ }^{2}$

\section{Learning points}

- The majority of cases of Tullio phenomenon are due to superior semicircular canal dehiscence.

- While the Tullio phenomenon is an unusual combination of signs and symptoms, a clinical history and focused examination are usually sufficient to make the diagnosis.

\section{Twitter Follow Richard Pullicino at @Rikardu}

Contributors Both RP and RG contributed in the formatting of the images and the description of the case.

Competing interests None declared.

Patient consent Obtained.

Provenance and peer review Not commissioned; externally peer reviewed.

\section{REFERENCES}

1 Kaski D, Davies $R$, Luxon $L$, et al. The Tullio phenomenon: a neurologically neglected presentation. J Neurol 2012;259:4-21.

2 Connor SEJ, Sriskandan N. Imaging of dizziness. Clin Radiol 2014:69:111-22.
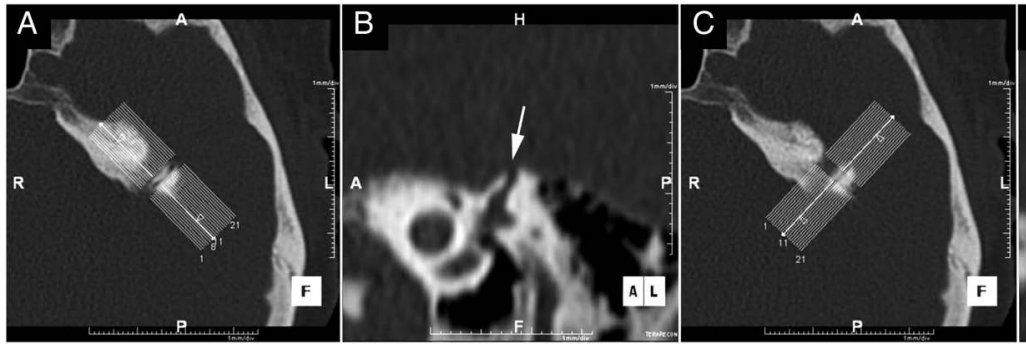

D

Figure 1 High-resolution $C T$ of the temporal bones reconstructed in the Stenvers ( $A$ and $B$ ) and Pöschl (C and D) planes demonstrating a bony defect in the apex of the superior semicircular canal ( $B$ and $D$, arrows).

Copyright 2015 BMJ Publishing Group. All rights reserved. For permission to reuse any of this content visit http://group.bmj.com/group/rights-licensing/permissions.

BMJ Case Report Fellows may re-use this article for personal use and teaching without any further permission.

Become a Fellow of BMJ Case Reports today and you can:

- Submit as many cases as you like

- Enjoy fast sympathetic peer review and rapid publication of accepted articles

- Access all the published articles

- Re-use any of the published material for personal use and teaching without further permission

For information on Institutional Fellowships contact consortiasales@bmjgroup.com

Visit casereports.bmj.com for more articles like this and to become a Fellow 